\title{
Active and uncontrolled asthma among children exposed to air stack emissions of sulphur dioxide from petroleum refineries in Montreal, Quebec: A cross-sectional study
}

\author{
Leylâ Deger MSc ${ }^{1}$, Céline Plante MSc ${ }^{1}$, Louis Jacques MD MOH CSPQ FRCPC ${ }^{1,2,3,4}$, Sophie Goudreau MSc(c) ${ }^{1}$, \\ Stéphane Perron MD MSc FRCPC ${ }^{1}$, John Hicks PhD ${ }^{5}$, Tom Kosatsky MD MPH ${ }^{6}$, Audrey Smargiassi PhD 2,7
}

\begin{abstract}
L Deger, C Plante, L Jacques, et al. Active and uncontrolled asthma among children exposed to air stack emissions of sulphur dioxide from petroleum refineries in Montreal, Quebec: A cross-sectional study. Can Respir J 2012;19(2):97-102.
\end{abstract}

BACKGROUND: Little attention has been devoted to the effects on children's respiratory health of exposure to sulphur dioxide $\left(\mathrm{SO}_{2}\right)$ in ambient air from local industrial emissions. Most studies on the effects of $\mathrm{SO}_{2}$ have assessed its impact as part of the regional ambient air pollutant mix. OBJECTIVE: To examine the association between exposure to stack emissions of $\mathrm{SO}_{2}$ from petroleum refineries located in Montreal's (Quebec) east-end industrial complex and the prevalence of active asthma and poor asthma control among children living nearby.

METHODS: The present cross-sectional study used data from a respiratory health survey of Montreal children six months to 12 years of age conducted in 2006. Of 7964 eligible households that completed the survey, 842 children between six months and 12 years of age lived in an area impacted by refinery emissions. Ambient $\mathrm{SO}_{2}$ exposure levels were estimated using dispersion modelling. Log-binomial regression models were used to estimate crude and adjusted prevalence ratios (PRs) and 95\% Cls for the association between yearly school and residential $\mathrm{SO}_{2}$ exposure estimates and asthma outcomes. Adjustments were made for child's age, sex, parental history of atopy and tobacco smoke exposure at home.

RESULTS: The adjusted PR for the association between active asthma and $\mathrm{SO}_{2}$ levels was 1.14 (95\% CI 0.94 to 1.39 ) per interquartile range increase in modelled annual $\mathrm{SO}_{2}$. The effect on poor asthma control was greater $\left(\mathrm{PR}=1.39\right.$ per interquartile range increase in modelled $\mathrm{SO}_{2}[95 \%$ CI 1.00 to 1.94$]$ ).

CONCLUSIONS: Results of the present study suggest a relationship between exposure to refinery stack emissions of $\mathrm{SO}_{2}$ and the prevalence of active and poor asthma control in children who live and attend school in proximity to refineries.

Key Words: Asthma; Children; Cross-sectional study; Dispersion modelling; Point source emissions; Sulphur dioxide

Cpidemiological studies suggest that exposure to air pollution is Eassociated with adverse consequences on children's respiratory health (1). Sulphur dioxide $\left(\mathrm{SO}_{2}\right)$, a gaseous respiratory irritant, is among the air pollutants of public health concern in urban and industrialized environments.

Most epidemiological investigations on the effects of $\mathrm{SO}_{2}$ have assessed its acute and chronic effects as a component of the regional ambient air pollutant mix. Panel studies involving children and time series analyses have documented associations between short-term (daily) exposure to regional $\mathrm{SO}_{2}$ levels and respiratory effects (eg, lung function changes, increased respiratory symptoms, emergency

\section{L'asthme actif et non contrôlé chez les enfants exposés à des émissions de dioxyde de soufre dans l'air en provenance des cheminées des raffineries de pétrole à Montréal, Québec : une étude transversale}

HISTORIQUE : On accorde peu d'attention aux effets de l'exposition au dioxyde de soufre $\left(\mathrm{SO}_{2}\right)$ présent dans l'air ambiant à cause des émissions industrielles locales sur la santé respiratoire des enfants. La plupart des études sur les effets du $\mathrm{SO}_{2}$ en ont évalué les répercussions d'après le mélange de polluants atmosphériques régionaux dans l'air ambiant.

OBJECTIF : Examiner l'association entre l'exposition aux émissions de $\mathrm{SO}_{2}$ en provenance des cheminées des raffineries de pétrole du complexe industriel de l'est de Montréal (au Québec) et la prévalence d'asthme actif et d'asthme mal contrôlé chez les enfants qui vivent à proximité.

MÉTHODOLOGIE : La présente étude transversale faisait appel à des données tirées d'une enquête sur la santé respiratoire des enfants montréalais de six mois à 12 ans menée en 2006. Parmi les 7964 ménages admissibles qui ont répondu à l'enquête, 842 enfants de six mois à 12 ans habitaient dans un quartier touché par les émissions des raffineries. Les chercheurs ont évalué les taux d'exposition au $\mathrm{SO}_{2}$ ambiant par modélisation de la dispersion et utilisé des modèles de régression log-binomiale pour évaluer les ratios de prévalence (RP) bruts et redressés et les IC à $95 \%$ pour établir l'association entre les évaluations d'exposition scolaire et résidentielle au $\mathrm{SO}_{2}$ et les issues de l'asthme. Ils ont procédé à des redressements selon l'âge, le sexe, les antécédents parentaux d'atopie et l'exposition à la fumée du tabac à la maison.

RÉSULTATS : Le RP redressé d'association entre l'asthme actif et les taux de $\mathrm{SO}_{2}$ correspondait à $1,14(95 \% \mathrm{IC} 0,94$ à 1,39$)$ par intervalle interquartile des modèles de $\mathrm{SO}_{2}$ annuels. L'effet sur le mauvais contrôle de l'asthme était plus élevé $(\mathrm{RP}=1,39$ par augmentation de l'intervalle interquartile dans les modèles de $\mathrm{SO}_{2}$ [95 \% IC 1,00 à 1,94]).

CONCLUSIONS : Les résultats de la présente étude laissent croire à un lien entre l'exposition aux émissions de $\mathrm{SO}_{2}$ par les cheminées des raffineries et la prévalence d'asthme actif et de mauvais contrôle de l'asthme chez les enfants qui vivent et fréquentent l'école à proximité des raffineries.

${ }^{1}$ Direction de santé publique de l'Agence de la santé et des services sociaux de Montréal; ${ }^{2}$ Département de santé environnementale et santé au travail;

${ }^{3}$ Département de médecine sociale et préventive, Université de Montréal; ${ }^{4}$ Clinique interuniversitaire de santé au travail et de santé

environnementale, Institut thoracique de Montréal, Montréal, Québec; ${ }^{5}$ Environmental and Resource Science Department, Trent University,

Peterborough, Ontario; ${ }^{6}$ British Columbia Centre for Disease Control, Vancouver, British Columbia; ${ }^{7}$ Institut national de santé publique du

Québec, Montréal, Québec

Correspondence: Dr Audrey Smargiassi. Institut national de santé publique du Québec / Direction de santé publique de Montréal, 1301 Sherbrooke

Est, Montréal, Québec H2L 1M3. Telephone 514-528-2400 ext 3226, fax 514-528-2459, e-mail asmargia@santepub-mtl.qc.ca 


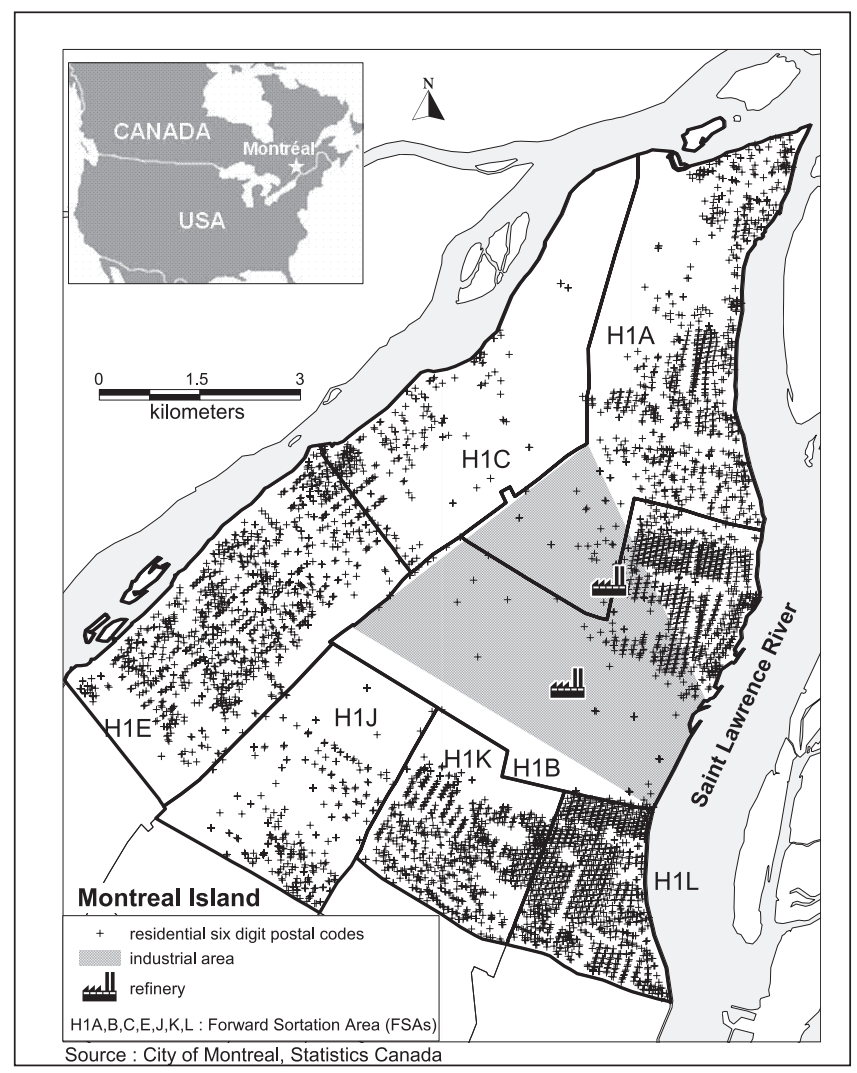

Figure 1) Study area, location of refineries and the industrial area, threecharacter postal areas (Forward Sortation Areas) and, residential six-character postal codes. A six-character postal code represents a segment of road (block side) on which approximately 50 individuals reside

Few studies have assessed the respiratory health effects of an individual's exposure within a community to industrial emissions of $\mathrm{SO}_{2}$. Refineries and power plants are among the well-known industrial facilities that contribute locally and regionally to ambient $\mathrm{SO}_{2}$ levels. The present study aimed to examine the effects of stack emissions of $\mathrm{SO}_{2}$ from petroleum refineries located in Montreal's (Quebec) eastend industrial complex on the prevalence of active asthma and poor asthma control among children six months to 12 years of age living in the vicinity of these industrial facilities. Data from a cross-sectional survey performed across the Island of Montreal on the prevalence of asthma was linked to dispersion model data from another study on acute effects performed in the same region (23). Dispersion modelling provides an approximation of ground-level concentrations of air pollutants around point sources and near housing, and can be used to quantify an individual's exposure, particularly over the long term, using averaged meteorological data (24).

\section{Study design and population}

\section{METHODS}

Between April and July 2006, a cross-sectional, population-based survey on the determinants of respiratory health in children was conducted on the Island of Montreal by the Montreal Public Health Department (25). Study participants were recruited from a random list of names and addresses of 17,697 Montreal households with at least one child between six months and 12 years of age, which was provided by the Quebec Health Insurance Board (RAMQ). To be eligible for the survey, the child had to reside in the Montreal area and live with the responding mother, father or legal guardian at least $50 \%$ of the time, and the child's parent or legal guardian had to be a French- or English-speaking adult ( $\geq 18$ years of age). These households received a letter inviting them to participate in the study. Furthermore,
12,680 households were matched with a telephone number, of which 3012 were nonvalid (eg, wrong numbers). The remaining 9668 households were contacted by telephone and 6813 (70\%) completed the survey, either by telephone or on the Internet. An additional 1167 households unpaired with a telephone number completed the web questionnaire (using the personal identification number for the Internet provided in the letter), yielding a total of 7980 completed questionnaires. The response rate for the households unpaired with a telephone number was estimated to be approximately $30 \%$. This response rate was estimated assuming, as for those contacted by telephone, that $76 \%$ (9668 of 12,680) of those unpaired with a telephone number (ie, 17,697-12,680) received the letter. The resulting overall response rate was, therefore, estimated to be approximately 60\% (7980 of 13,481). Overall, $52.3 \%$ answered the questionnaire on the Internet and $47.7 \%$ by telephone. In families that had more than one eligible child, the questionnaire was completed for the child whose birthday was nearest to the survey date.

In the present study, survey subjects who resided in the east end of the Island of Montreal, where an industrial sector comprising two petroleum refineries is located, were selected. This area is comprised of primarily working-class residents. The defined geographical area of the study corresponds to the Forward Sortation Areas (FSAs) H1A, H1B, H1K, H1L, H1C, H1E, and H1J (Figure 1). Residences in the study area defined by the seven FSAs are located as close as $0.4 \mathrm{~km}$ and up to $12.8 \mathrm{~km}$ from the refinery stacks (median $3.6 \mathrm{~km}$ ). Schools in the area are $1.0 \mathrm{~km}$ to $8.8 \mathrm{~km}$ from the stacks (median $4.2 \mathrm{~km}$ ). To limit exposure misclassification due to moving, children who resided within any of the seven FSAs since birth or who had lived at the same address in the study area for $\geq 1$ year before the 2006 survey were selected.

From the 7980 completed questionnaires, 842 met the residency inclusion criteria (in the east end of the Island of Montreal since birth or for $\geq 1$ year). The response rate among the east-end Montreal population was similar to that for the entire sample (see above), and was estimated to be $65 \%$. In the east end of the Island of Montreal, $50.4 \%$ answered the questionnaire on the Internet and $49.6 \%$ by telephone.

The questionnaire was based on the International Study of Asthma and Allergies in Childhood (ISAAC) and the European Community Respiratory Health Survey (ECHRS) standardized written questionnaires, as well as the Quebec Child and Adolescent Health and Social Survey, to ensure comparability between Canadian and International results. Survey and asthma experts were asked to review the questionnaire, and a small-scale pretest was performed for content validation. Questions focused on the child's respiratory and allergy symptoms and illnesses, use of health care services, personal and family medical history, home environmental exposures, lifestyle factors and sociodemographic characteristics. Home postal codes (six characters) were requested from the respondents. Within the study area, a six-digit postal code often corresponds to a single segment of road on which fewer than 50 individuals reside. A question about the location of the school the child attended (when applicable) was also included. Written informed consent was obtained from the child's parent or legal guardian. The study protocol was approved by the Montreal Public Health Research Ethics Board.

\section{Study variables}

Health outcomes: The definition of active asthma in Health Canada's 1995-1996 Student Lung Health Survey was used (26). 'Active asthma' was defined as ever having being diagnosed with asthma by a physician and having reported one or more of the following features during the 12 months preceding the survey: wheezing or whistling in the chest, a dry cough at night, an asthma attack or use of bronchodilators.

'Asthma control' was established in subjects with 'active asthma' and was assessed on the basis of five specific symptom-based criteria that are similar to those in the Canadian Pediatric Asthma Consensus guidelines (27). Asthma was considered poorly controlled if one or more of the following features was reported: daytime symptoms (eg, wheezing or whistling in the chest $\geq 3$ times a week); night-time 
symptoms (eg, awakened by dry cough or wheezing $\geq 1$ night a week); the need for $\geq 3$ doses a week of short-acting beta-2-agonist rescue medication; physical activity limitations during the previous three months; or absence from school or daycare due to asthma during the previous three months. The survey questions related to these outcomes are listed in Appendix 1.

Individual characteristics: The individual characteristics of children were age as linear spline basis functions with one knot at six years of age chosen on the basis of the relationship between asthma prevalence and age; sex; parental history of atopy defined as a reported history of asthma, allergic rhinitis or eczema in the child's biological mother or father; household income ( $<\$ 75,000 /$ year or $\geq \$ 75,000 /$ year, based on the second tercile); maternal educational level (secondary or less, or postsecondary); and environmental tobacco smoke (ETS) exposure defined as any current (eg, at the time of survey) exposure to smoking in the home.

Residential and school exposure to $\mathrm{SO}_{2}$ : The geographical location of a child's home and school within the seven FSAs was estimated using the centroid coordinates of the six-digit postal codes.

Yearly ambient $\mathrm{SO}_{2}$ levels from refinery stack emissions were estimated at the locations of the centroid coordinates of these six-digit postal codes. They were computed from hourly $\mathrm{SO}_{2}$ levels using the AERMOD air dispersion model as described in an earlier study that assessed their acute respiratory effects (23). This model is recommended by the United States Environmental Protection Agency for estimating the concentration of pollutants at specific ground-level receptors surrounding an emission source (28). Refinery emissions of $\mathrm{SO}_{2}$ and meteorological data for 2004 were used because 2005 emission data were not available.

Briefly, data for several point-source emissions of the two refineries were used to model hourly $\mathrm{SO}_{2}$ levels at receptor locations corresponding to the residential six-digit postal code centroids in the east end of Montreal (in the FSAs H1A, H1B, H1K, H1L, H1C, H1E and H1J). The point-source emissions included those from main vents and stacks that emit continuously throughout the year (seven point-source emission sources for one refinery and five for the other). Data regarding the longitude/latitude, emission temperature, height and exit velocity for each vent and stack were available. The emissions from the main vents and stacks represented approximately $90 \%$ of the total $\mathrm{SO}_{2}$ emissions from the two refineries. From 1994 to 2005, emissions from the two refineries represented more than $80 \%$ of the industrial $\mathrm{SO}_{2}$ emissions in the area (>7500 tons/year according to the Canadian National Pollutant Release Inventory) (29).

The inputs to the dispersion model also included hourly meteorological records from the Pierre Elliott Trudeau Montreal International Airport, approximately $25 \mathrm{~km}$ from the study area, and upper air data from a rural monitoring site descriptive of the greater Montreal region. All meteorological data were acquired from Environment Canada (30). The topographical characteristics across the area of interest were considered to be constant. Allowances in the model were made for the nature of the local terrain, including both vegetated (grass) and paved surfaces.

Attempts were made to account for the time-activity patterns of all selected study children. For children younger than than five years of age on September 30, 2005 (compulsory school attendance age cut-off date each year), who were assumed to spend most of their time at home, hourly $\mathrm{SO}_{2}$ exposure estimates included only home exposure values. For school-age children (between five and 12 years of age), the time spent at home and at school was considered: it was assumed that $8 \mathrm{~h}$ a day (08:00 to 16:00) was spent at school on weekdays (Monday to Friday) from September to June and that the remaining time was spent at home. A missing $\mathrm{SO}_{2}$ value for school exposure was assigned to children attending schools outside the area of east-end Montreal (11.7\%). Background ambient $\mathrm{SO}_{2}$ levels were not considered because only one average value at the monitoring station was available for the Island of Montreal (a constant for all the children in the present study). For the analyses, intra-urban geographical variations in pollutant levels emitted by industrial stacks were available only for $\mathrm{SO}_{2}$.

\section{Data analysis}

Two different sets of analyses were performed according to the prevalence of the two defined outcomes: children with active asthma and children with poor asthma control. Cases with missing data ("do not know" or "refusal") for any of the variables included in the analyses were excluded.

Descriptive analyses estimated the frequency distribution of the study population characteristics (child's age and sex, parental history of atopy, household income, maternal education level, maternal immigration status, ETS exposure and yearly $\mathrm{SO}_{2}$ exposure), comparing children with the disease with those without the disease as outlined above. $\chi^{2}$ tests were used for categorical variables and $t$ tests for continuous variables.

Log-binomial regression models were used to estimate crude and adjusted prevalence ratios (PRs) with corresponding 95\% CIs for the association between yearly $\mathrm{SO}_{2}$ exposure levels (AERMOD estimates) and asthma outcomes. Potential confounders included child's age and sex, parental history of atopy and ETS exposure at home. The PRs are expressed per interquartile range of yearly $\mathrm{SO}_{2}$ levels $\left(\mathrm{SO}_{2}\right.$ interquartile range $\left.4.7 \mu \mathrm{g} / \mathrm{m}^{3}\right)$. All statistical analyses were performed using STATA version 9.2 (STATA Corporation, USA).

\section{Study population characteristics}

\section{RESULTS}

Of the 842 eligible respondents who completed the survey, a total of $821(97.5 \%)$ provided complete questionnaire data to establish the child's asthma status and potential confounder variables.

A total of $652(79.4 \%$ of 821$)$ children had not been previously diagnosed with asthma. Among those ever diagnosed with asthma by a physician ( $n=169), 142(17.3 \%$ of 821$)$ experienced active asthma in the previous year. Of these, $35.9 \%$ met at least one of the five criteria of poor asthma control and five could not be evaluated because of missing data (6.2\% [51 of 816]). For comparison, the prevalence of active and uncontrolled asthma was $12.8 \%$ and $4.5 \%$, respectively, for the entire population of children in Montreal.

The characteristics of the study population are summarized in Table 1. No significant differences were found with respect to age according to asthma status. The proportion of boys was higher among children with poor asthma control (60.8\%) compared with the rest of the children (ie, no asthma or controlled asthma [49.9\%]). Parental history of atopy was lowest $(33.0 \%)$ among children who were not asthmatic. Asthmatic subjects were also more likely to be in lower socioeconomic groups (ie, low household income and maternal education)

\section{Associations between AERMOD $\mathrm{SO}_{2}$ exposure levels and asthma outcomes}

The crude and adjusted PRs of association for asthma outcomes with yearly total AERMOD $\mathrm{SO}_{2}$ estimates are presented in Table 2. The estimated crude and multivariate-adjusted PRs demonstrate a tendency toward an association between active asthma in children from east-end Montreal, and residential and school $\mathrm{SO}_{2}$ concentrations. A significant and more marked association was found between poor asthma control and $\mathrm{SO}_{2}$ concentrations (crude PR 1.45 [95\% CI 1.03 to 2.03] and adjusted PR 1.39 [95\% CI 1.00 to 1.94 ] per interquartile range). Adjusting for child's age and sex, parental atopy and ETS exposure slightly decreased the PRs. Stratification according to age $(<6$ years of age and $\geq 6$ years of age) showed that associations with $\mathrm{SO}_{2}$ were mainly observed in the older age group (data not shown). Adjusting for socioeconomic status (ie, household income and maternal educational level) had limited influence on the results of the analyses $(<5 \%$, data not shown).

\section{DISCUSSION}

The present study demonstrated an association between the prevalence of active and poor asthma control among children living in east-end 
TABLE 1

Characteristics of children from east-end Montreal (Quebec), 2006

\begin{tabular}{|c|c|c|c|c|c|}
\hline Variable & $\begin{array}{l}\text { Active asthma } \\
\qquad(n=142)\end{array}$ & $\begin{array}{l}\text { No active asthma } \\
\qquad(n=679)\end{array}$ & $\begin{array}{l}\text { Poor asthma control* } \\
\qquad(n=51)\end{array}$ & $\begin{array}{l}\text { Active asthma with } \\
\text { acceptable control* } \\
\qquad(n=86)\end{array}$ & $\begin{array}{c}\text { No asthma or } \\
\text { controlled asthma } \\
(n=765)\end{array}$ \\
\hline Age, years, mean $\pm S D$ & $7.6 \pm 2.7$ & $7.5 \pm 3.3$ & $7.2 \pm 2.7$ & $7.6 \pm 2.7$ & $7.5 \pm 3.3$ \\
\hline \multicolumn{6}{|l|}{ Sex, n (\%) } \\
\hline Male & $72(50.7)$ & $345(50.8)$ & $31(60.8)^{\dagger}$ & $37(43.0)$ & $382(49.9)$ \\
\hline Female & $70(49.3)$ & $334(49.2)$ & $20(39.2)$ & $49(57.0)$ & $383(50.1)$ \\
\hline Parental history of atopy, n (\%) & $90(63.4)^{\ddagger}$ & $224(33.0)$ & $34(66.7)^{\S}$ & $51(59.3)$ & $275(36.0)$ \\
\hline \multicolumn{6}{|l|}{ Household income/year, n (\%) } \\
\hline$<\$ 75,000$ & $96(73.8)^{\dagger}$ & $393(64.5)$ & $36(75.0)$ & $57(73.1)$ & $450(65.5)$ \\
\hline$\geq \$ 75,000$ & $34(26.2)$ & $216(35.5)$ & $12(25.0)$ & $21(26.9)$ & $237(34.5)$ \\
\hline \multicolumn{6}{|l|}{ Maternal educational level, $\mathrm{n}(\%)^{\star \star}$} \\
\hline Secondary and lower & $54(39.1)$ & $212(32.0)$ & $19(37.3)$ & $33(40.2)$ & 245 (32.9) \\
\hline Postsecondary & $84(60.9)$ & $451(68.0)$ & $32(62.7)$ & $49(59.8)$ & $500(67.1)$ \\
\hline Passive smoke exposure, n (\%) & $28(19.7)$ & $125(18.4)$ & $10(19.6)$ & $16(18.6)$ & $141(18.4)$ \\
\hline Yearly $\mathrm{SO}_{2}$ exposure, $\mu \mathrm{g} / \mathrm{m}^{3}$, mean $\pm \mathrm{SD}$ & $4.75(3.24)$ & $4.37(3.17)$ & $5.37(3.50)^{\dagger \dagger}$ & $4.55(3.09)$ & $4.39(3.2)$ \\
\hline
\end{tabular}

*Assessment of asthma control was not possible for five active asthmatic subjects, thus, the number of controlled and uncontrolled asthmatics does not sum to 142; ${ }^{\dagger}$ Significant difference from the group of children without active asthma $\left(\chi^{2} P<0.05\right)$; ${ }^{\ddagger}$ Significant difference from the group of children without active asthma ( ${ }^{2}$ $P<0.001)$; ' SSignificant difference from the group of children with no asthma or controlled asthma $\left(\chi^{2} P<0.001\right)$; "Eighty-two individuals had missing values ( $\left.n=739\right)$; ${ }^{* *}$ Twenty individuals had missing values ( $\left.n=801\right) ;{ }^{\dagger+}$ Significant difference from the group of children with no asthma or controlled asthma (t test $\left.P<0.05\right)$. SO ${ }_{2}$ Sulphur dioxide

TABLE 2

Prevalence ratios (PR) for the association between yearly ambient sulphur dioxide exposure levels (AERMOD estimates) and prevalence of active asthma and poor asthma control

\begin{tabular}{lrrcc}
\hline Health outcomes & Yes & No & PR (95\% Cl) & PR (95\% Cl)* \\
\hline Active asthma & 142 & 679 & $1.15(0.94-1.41)$ & $1.14(0.94-1.39)$ \\
Poor asthma control $^{\dagger}$ & 51 & 765 & $1.45(1.03-2.03)$ & $1.39(1.00-1.94)$ \\
\hline
\end{tabular}

*Expressed as an interquartile range (IQR) increase and adjusted for child's age, sex, parental atopy and environmental tobacco smoke exposure at home; there were missing data for the questions used for the assessment of asthma control in five children

Montreal, and ambient school and residential exposure to refinery stack emissions of $\mathrm{SO}_{2}$. In the present study, $\mathrm{SO}_{2}$ exposure was estimated using a dispersion model, which provided the intra-urban geographical variation of ambient $\mathrm{SO}_{2}$ levels. In earlier studies, the association between industrial $\mathrm{SO}_{2}$ emissions and respiratory health effects among children was assessed by comparing large geographical areas with different $\mathrm{SO}_{2}$ levels or areas in varying proximity to industrial facilities that burn coal or oil, such as power plants, refineries, incinerators, petrochemical complexes and other industrial sources of $\mathrm{SO}_{2}(31)$.

Our results concur with those of Charpin et al (32), Dales et al (33) and Yang et al (34) who reported an increased prevalence of respiratory symptoms in industrial-polluted communities with higher levels of $\mathrm{SO}_{2}$ compared with low-pollution areas. Our results are also in agreement with studies reporting an increased prevalence of asthma (35-37) or asthma-related symptoms (37-39) among children living in proximity to industrial areas, including refineries and petrochemical plants, where $\mathrm{SO}_{2}$ emissions occur.

The prevalence of parental atopy was quite high in our study (more than $60 \%$ in children with active asthma and poor control of their disease, and $33 \%$ in children without asthma). Some previous studies that measured parental atopy using questionnaires reported widely varying prevalences of positive parental history of atopy in asthmatic children, for example, ranging from $15 \%$ (family history of asthma) to 28\% (mother has asthma) among Canadian children with asthma $(40,41)$. In these studies, different approaches were used to define the presence of atopy (42). The differences observed between our study and previous work could partly result from the fact that we used a more inclusive definition (ie, a reported history of asthma, allergic rhinitis and/or eczema in the child's biological mother or father) to capture a variety of parental atopy profiles associated with asthma. The higher prevalence of parental atopy in this population could also be due to a much lower proportion of immigrants living in the area (the lowest on the Island of Montreal). In fact, the prevalence of declared parental atopy among immigrants was approximately one-half of that among the domestic population (North American origin) (25).

Furthermore, other studies did not find an association between proximity to areas with $\mathrm{SO}_{2}$-emitting industrial facilities and asthma-related outcomes $(43,44)$. These inconsistencies may be due to the fact that most studies failed to properly classify exposure. Exposure may be better estimated with the use of dispersion modelling than by proximity to industrial facilities.

While a dispersion model was used to estimate exposure, our study was still subject to several limitations. First, definitive information regarding the residency of the children was not available. Our schoolresidence weighted time may not have been an adequate representation of exposure. We assumed that children who were younger than five years of age were at home; however, some were likely attending daycare, but the location of the daycare centres was not available. Nevertheless, school and daycare hours are small compared with home hours, and would have limited influence on annual exposure estimates. In support of this, when we used home exposure data only (ie, without school exposure), similar results were observed.

Second, the exposure estimates did not include other sources of $\mathrm{SO}_{2}$. We focused on the contribution of $\mathrm{SO}_{2}$ emissions from the refineries because it was the main source of this pollutant in the study area. Background $\mathrm{SO}_{2}$ emissions from other local industrial sources or from diverse urban sources were considered to be neglible.

Third, we do not know whether the effects observed in our study were due to $\mathrm{SO}_{2}$, to other pollutants or to a combination of both. Stack emissions of other pollutants such as fine particles, which have been associated with asthma, occur concurrently with $\mathrm{SO}_{2}$. Fugitive volatile organic compound (VOC) and stack emissions are dispersed to residential areas by winds and expose the population. Unfortunately, we could not address the effects of VOC and fine particulate emissions in our analyses because the levels of these pollutants were not modelled. Furthermore, we do not know whether the effects were due to cumulative or recent exposure. Pollutant levels and refinery 
emissions were higher in the past and, for older children, exposure might have been higher in the early years of life. However, asthma control is probably more influenced by recent exposure.

Given the multifactorial etiology of asthma, it is also possible that pollutants derived from indoor sources contribute to the aggravation of the disease. Yet, we controlled for ETS exposure in the home - the most probable confounder or effect modifier among environmental and lifestyle risk factors for asthma. Analyses controlling for the presence of reported mold or humidity in the house, as well as road traffic density on the street of the residence were also performed, with no confounders to the associations with $\mathrm{SO}_{2}$ levels observed (data not shown).

It is also worth noting that in the current study, asthma diagnosis and asthma status (active asthma and disease control) were not validated with objective measurements such as lung function tests. Nevertheless, the methods we used were similar to those of other national and international epidemiological studies that used validated and standardized questionnaires. We also assessed asthma symptoms and control using criteria and questions that are widely used in clinical practices involving children. We should also point out that asthma cannot be definitely confirmed in children younger than six years of age, and that the diagnosis of asthma is not based on physiological criteria for that age group $(27,45)$.

Finally, the high level of public concern about the health impacts of refinery pollution might have led subjects to move away from the industrial sector, which might have influenced our prevalence results. To limit the effect of moving, we studied only children who resided at the same address in the study area for at least one year before the 2006 survey or since birth. Furthermore, public concern might have led subjects living near the refineries to over-report respiratory health symptoms. While differential reporting bias was not ruled out, the initial study was presented as a respiratory health survey of Montreal children rather than an assessment of the respiratory health effects from exposure to refinery emissions, thereby reducing such bias. Furthermore, the use of a dispersion model to estimate exposure, rather than only proximity to the industrial complex, renders differential reporting of asthma symptoms according to exposure category less likely.

\section{CONCLUSION}

Results of the present study suggest an association between exposure to $\mathrm{SO}_{2}$ from refinery stack emissions and the prevalence of active and poor asthma control. Additional studies are needed to understand whether the observed associations were due to repeat acute or chronic exposure or to both, and if industrial emissions are associated with the development of asthma.

ACKNOWLEDGEMENTS: The authors thank F Tessier, G Morneau, Y Bourassa, and Y Otis for technical support, Environment Canada and the City of Montreal for air pollution and meteorological data, and the Montreal refineries that provided emission data. This study was funded by the Quebec

\section{REFERENCES}

1. Bates DV. The effects of air pollution on children.

Environ Health Perspect 1995;103:49-53.

2. Boezen HM, van der Zee SC, Postma DS, et al. Effects of ambient air pollution on upper and lower respiratory symptoms and peak expiratory flow in children. The Lancet 1999;353:874-8.

3. Neas LM, Dockery DW, Koutrakis P, Tollerud DJ, Speizer FE. The association of ambient air pollution with twice daily peak expiratory flow rate measurements in children.

Am J Epidemiol 1995;141:111-22.

4. Peters A, Goldstein IF, Beyer U, et al. Acute health effects of exposure to high levels of air pollution in eastern Europe. Am J Epidemiol 1996;144:570-81.

5. Roemer W, Hoek G, Brunekreef B. Effect of ambient winter air pollution on respiratory health of children with chronic respiratory symptoms. Am Rev Respir Dis 1993;147:118-24.
Ministry of Health and Social Services and by Direction de santé publique de l'Agence de la santé et des services sociaux de Montréal.

COMPETING INTERESTS: The authors have no competing interests to declare.

AUTHORS' CONTRIBUTIONS: LJ was responsible for the design and the implementation of the 'parent study' (ie, Respiratory health survey in Montreal children). AS conceived the present study design. LD and AS performed the literature review and drafted the manuscript. JH developed the dispersion model. SG and CP performed the analysis and assisted in manuscript preparation, particularly the Methods and Results sections. TK provided guidance for the 'parent' and the present studies. All authors contributed to data interpretation and manuscript preparation.

\section{APPENDIX 1}

Health outcomes: Asthma assessment questions

\section{Active asthma}

Has a doctor ever said your child had asthma?

And, in the past 12 months, did your child have one or more of the following:

- ... wheezing or whistling in the chest?

- ... a dry cough at night?

- ... an attack of asthma?

- ... did your child use any medication against asthma (pumps, nebulizers, syrup or injection)?

Asthma control (applied to subjects with active asthma only)

Active asthma not under control if one or more of these features were reported:

- Currently, does your child wheeze or have a whistling sound in the chest three times or more a week?

- Currently, is your child awakened at night by a dry cough or by wheezing one time or more a week?

- During the past 3 months, has your child limited or avoided physical activities because of his/her asthma?

- During the past 3 months, has your child missed school or daycare, because of his/her asthma?

- At the time of the survey, the child used frequently (ie, $\geq 3$ times per week) a bronchodilator for asthma

The following questions were used to assess frequent bronchodilator use (a positive answer to the first question below was mandatory and one of the two other features was necessary to identify children using a bronchodilatator $\geq 3$ times per week:

i) Does your child use a bronchodilatator, such as Ventolin*? (Yes)

ii) How often does your child use the bronchodilatator ? (everyday, a few times per week)

iii) If the answer to the previous questions was 'a few times per week, the respondent was asked: Does your child use the bronchodilatator three times or more a week? (Yes)

*GlaxoSmithKline, USA

6. Schwartz J, Dockery DW, Neas LM, et al. Acute effects of summer air pollution on respiratory symptom reporting in children. Am J Respir Crit Care Med 1994;150:1234-42.

7. Segala C, Fauroux B, Just J, Pascual L, Grimfeld A, Neukirch F. Short-term effect of winter air pollution on respiratory health of asthmatic children in Paris. Eur Respir J 1998;11:677-85.

8. Timonen KL, Pekkanen J. Air pollution and respiratory health among children with asthmatic or cough symptoms. Am J Respir Crit Care Med 1997;156:546-52.

9. Buchdahl R, Parker A, Stebbings T, Babiker A. Association between air pollution and acute childhood wheezy episodes: Prospective observational study. BMJ 1996;312:661-5.

10. Barnett AG, Williams GM, Schwartz J, et al. Air pollution and child respiratory health: A case-crossover study in Australia and New Zealand. Am J Respir Crit Care Med 2005;171:1272-8. 
11. Braun-Fahrlander C, Vuille JC, Sennhauser FH, et al. Respiratory health and long-term exposure to air pollutants in Swiss schoolchildren. SCARPOL Team. Swiss Study on Childhood Allergy and Respiratory Symptoms with Respect to Air Pollution, Climate and Pollen. Am J Respir Crit Care Med 1997;155:1042-9.

12. Chapman RS, Calafiore DC, Hasselblad V. Prevalence of persistent cough and phlegm in young adults in relation to long-term ambient sulfur oxide exposure. Am Rev Respir Dis 1985;132:261-7.

13. Dockery DW, Cunningham J, Damokosh AI, et al. Health effects of acid aerosols on North American children: Respiratory symptoms. Environ Health Perspect 1996;104:500-5.

14. Herbarth O, Fritz G, Krumbiegel P, Diez U, Franck U, Richter M. Effect of sulfur dioxide and particulate pollutants on bronchitis in children - a risk analysis. Environmental Toxicology 2001;16:269-76.

15. Hirsch T, Weiland SK, von Mutius E, et al. Inner city air pollution and respiratory health and atopy in children. Eur Respir J 1999;14:669-77.

16. Penard-Morand C, Charpin D, Raherison C, et al. Long-term exposure to background air pollution related to respiratory and allergic health in schoolchildren. Clin Exp Allergy 2005;35:1279-87.

17. Pikhart H, Bobak M, Gorynski P, et al. Outdoor sulphur dioxide and respiratory symptoms in Czech and Polish school children: A small-area study (SAVIAH). Small-Area Variation in Air Pollution and Health. Int Arch Occup Environ Health 2001;74:574-8.

18. Ware JH, Ferris BG Jr, Dockery DW, Spengler JD, Stram DO, Speizer FE. Effects of ambient sulfur oxides and suspended particles on respiratory health of preadolescent children. Am Rev Respir Dis 1986;133:834-42

19. Hoek G, Brunekreef B. Acute effects of a winter air pollution episode on pulmonary function and respiratory symptoms of children. Arch Environ Health 1993;48:328-35.

20. Roemer W, Hoek G, Brunekreef B, Haluszka J, Kalandidi A, Pekkanen J. Daily variations in air pollution and respiratory health in a multicentre study: The PEACE project. Pollution Effects on Asthmatic Children in Europe. Eur Respir J 1998;12:1354-61.

21. Schildcrout JS, Sheppard L, Lumley T, Slaughter JC, Koenig JQ, Shapiro GG. Ambient air pollution and asthma exacerbations in children: An eight-city analysis. Am J Epidemiol 2006;164:505-17.

22. Dockery DW, Speizer FE, Stram DO, Ware JH, Spengler JD, Ferris BG Jr. Effects of inhalable particles on respiratory health of children. Am Rev Respir Dis 1989;139:587-94.

23. Smargiassi A, Kosatsky T, Hicks J, et al. Risk of asthmatic episodes in children exposed to sulfur dioxide stack emissions from a refinery point source in Montreal, Canada. Environ Health Perspect 2009;117:653-9.

24. Kibble A, Harrison R. Point sources of air pollution. Occup Med (Lond) 2005;55:425-31.

25. Jacques L, Plante C, Goudreau S, et al. Rapport synthèse régional de l'étude sur la santé respiratoire des jeunes Montréalais de 6 mois à 12 ans. Montréal: Direction de santé publique de l'Agence de la santé et des services sociaux de Montréal, 2011, ISBN 978-2-89673. 045-2 (printed version), ISBN 978-2-89673-046-9 (PDF document).

26. Santé Canada. L'asthme infantile dans les secteurs desservis par les unités de santé sentinelles. Rapport des résultats de l'Enquête sur la santé pulmonaire des jeunes 1995-1996. Système de surveillance par unité de santé sentinelle - volet asthme. Ottawa: Division des maladies respiratoires; Bureau des maladies cardio-respiratoires et du diabète; Laboratoire de lutte contre la maladie, 1998 0-662-83351-1 Contract No.: 9 novembre 2007.

27. Becker A, Berube D, Chad Z, et al. Canadian Pediatric Asthma Consensus guidelines, 2003 (updated to December 2004): Introduction. CMAJ 2005;173:S12-4.

28. U.S. Environmental Protection Agency. Support Center for Regulatory Atmospheric Modeling. <www.epa.gov/scram001/ dispersion_prefrec.htm> (Accessed July 7, 2008).

29. National Pollutant Release Inventory Online Data Search. $<$ www.ec.gc.ca/pdb/websol/querysite/query_e.cfm/> (Accessed July 7, 2008).

30. Environnement Canada. National Climate Data and Information Archive. <www.climat.meteo.ec.gc.ca/climateData/canada_e.html> (Accessed on July 7, 2008).

31. U.S. Environmental Protection Agency. Integrated Science Assessment (ISA) for Sulfur Oxides - Health Criteria (Final Report). Report EPA/600/R-08/047F. Washington DC: U.S. Environmental Protection Agency, 2008.

32. Charpin D, Kleisbauer JP, Fondarai J, Graland B, Viala A, Gouezo F. Respiratory symptoms and air pollution changes in children: The Gardanne Coal-Basin Study. Arch Environ Health 1988;43:22-7.

33. Dales RE, Spitzer WO, Suissa S, Schechter MT, Tousignant P, Steinmetz N. Respiratory health of a population living downwind from natural gas refineries. Am Rev Respir Dis 1989;139:595-600.

34. Yang CY, Wang JD, Chan CC, Hwang JS, Chen PC. Respiratory symptoms of primary school children living in a petrochemical polluted area in Taiwan. Pediatr Pulmonol 1998;25:299-303.

35. Forastiere F, Corbo GM, Pistelli R, et al. Bronchial responsiveness in children living in areas with different air pollution levels. Arch Environ Health 1994;49:111-8.

36. Henry RL, Abramson R, Adler JA, Wlodarcyzk J, Hensley MJ. Asthma in the vicinity of power stations: I. A prevalence study. Pediatric Pulmonol 1991;11:127-33.

37. White N, teWaterNaude J, van der Walt A, Ravenscroft G, Roberts W, Ehrlich R. Meteorologically estimated exposure but not distance predicts asthma symptoms in schoolchildren in the environs of a petrochemical refinery: A cross-sectional study. Environ Health 2009;8:45.

38. Wichmann FA, Muller A, Busi LE, et al. Increased asthma and respiratory symptoms in children exposed to petrochemical pollution. J Allergy Clin Immunol 2009;123:632-8.

39. Halliday JA, Henry RL, Hankin RG, Hensley MJ. Increased wheeze but not bronchial hyperreactivity near power stations. J Epidemiol Community Health 1993;47:282-6.

40. Millar WJ, Hill GB. Childhood asthma. Health Reports (Statistics Canada, Catalogue 82-003) 1998;10:9-21.

41. Lévesque B, Rhainds M, Ernst P, et al. Asthma and allergic rhinitis in Quebec children. Can Respir J 2004;11:343-8.

42. Burke W, Fesinmeyer M, Reed K, Hampson L, Carlsten C. Family history as predictor of asthma risk. Am J Prev Med 2003; 24:160-9.

43. Bhopal RS, Phillimore P, Moffatt S, Foy C. Is living near a coking works harmful to health? A study of industrial air pollution. J Epidemiol Comm Health 1994;48:237-47.

44. Ramadour M, Burel C, Lanteaume A, et al. Prevalence of asthma and rhinitis in relation to long-term exposure to gaseous air pollutants. Allergy 2000;55:1163-9.

45. Global Initiative For Asthma. Global Strategy for the Diagnosis and Management of Asthma in Children 5 Years and Younger. $<$ www.ginasthma.org $>$ (Accessed October 1, 2008). 


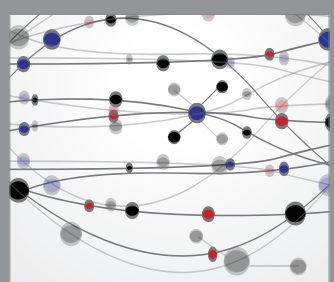

The Scientific World Journal
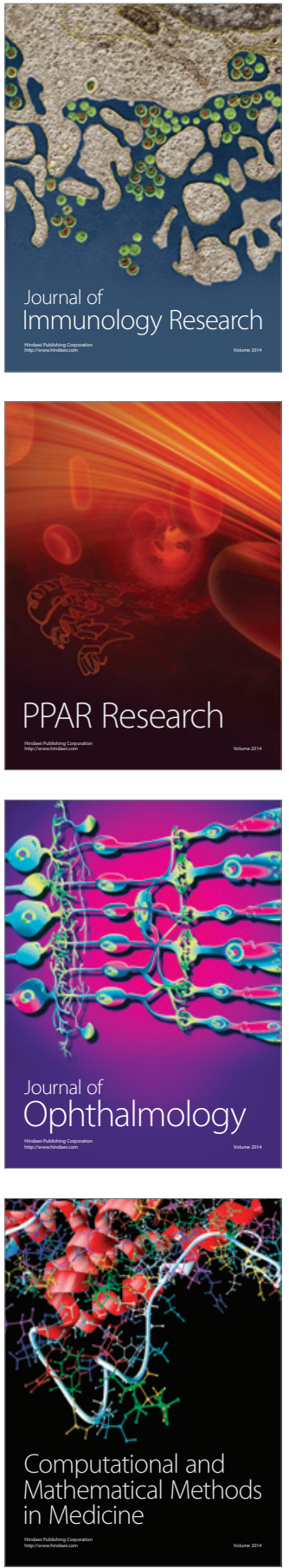

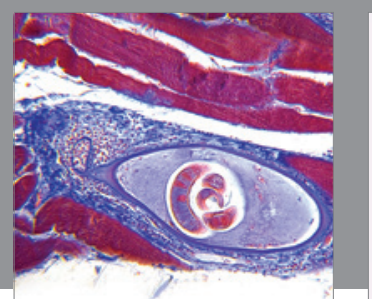

Gastroenterology Research and Practice

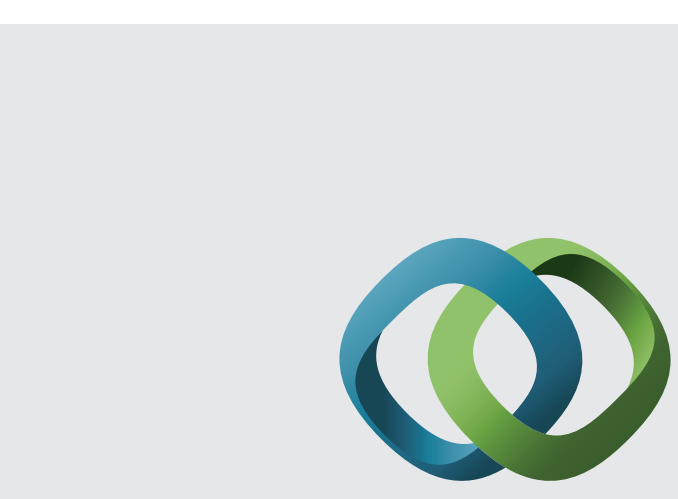

\section{Hindawi}

Submit your manuscripts at

http://www.hindawi.com
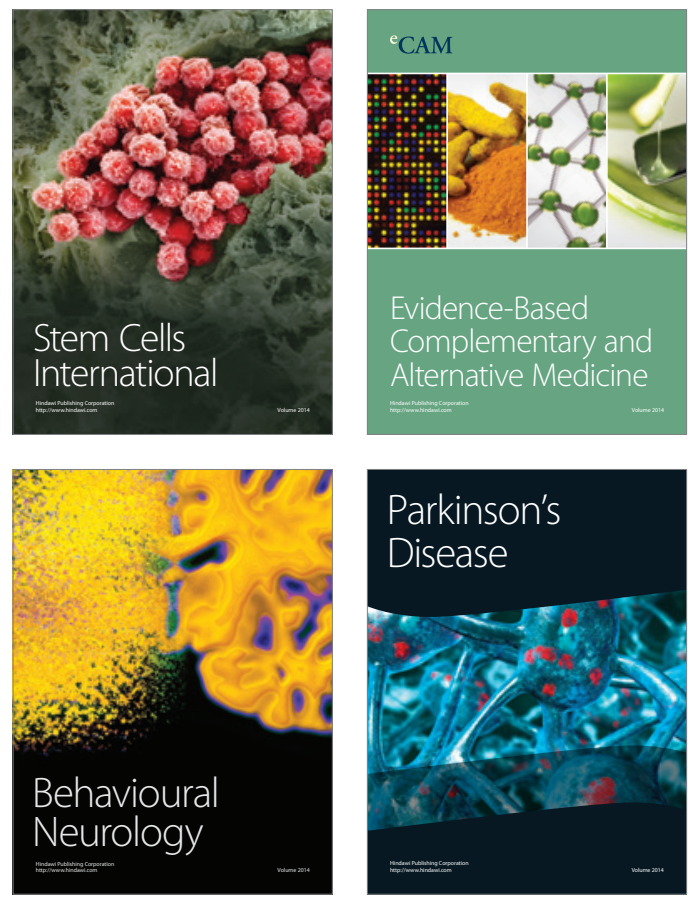
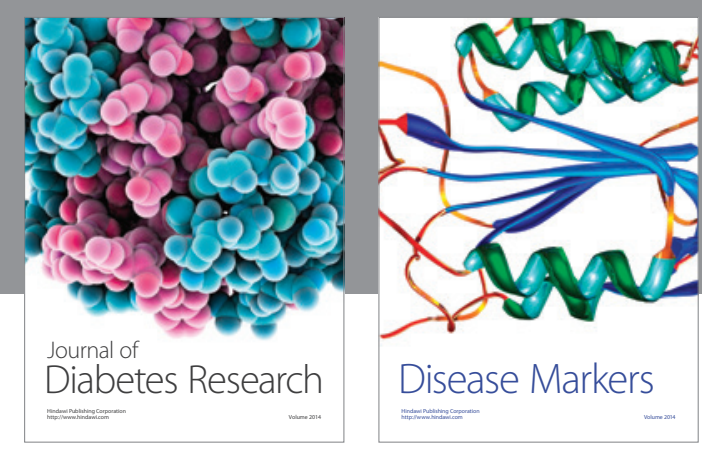

Disease Markers
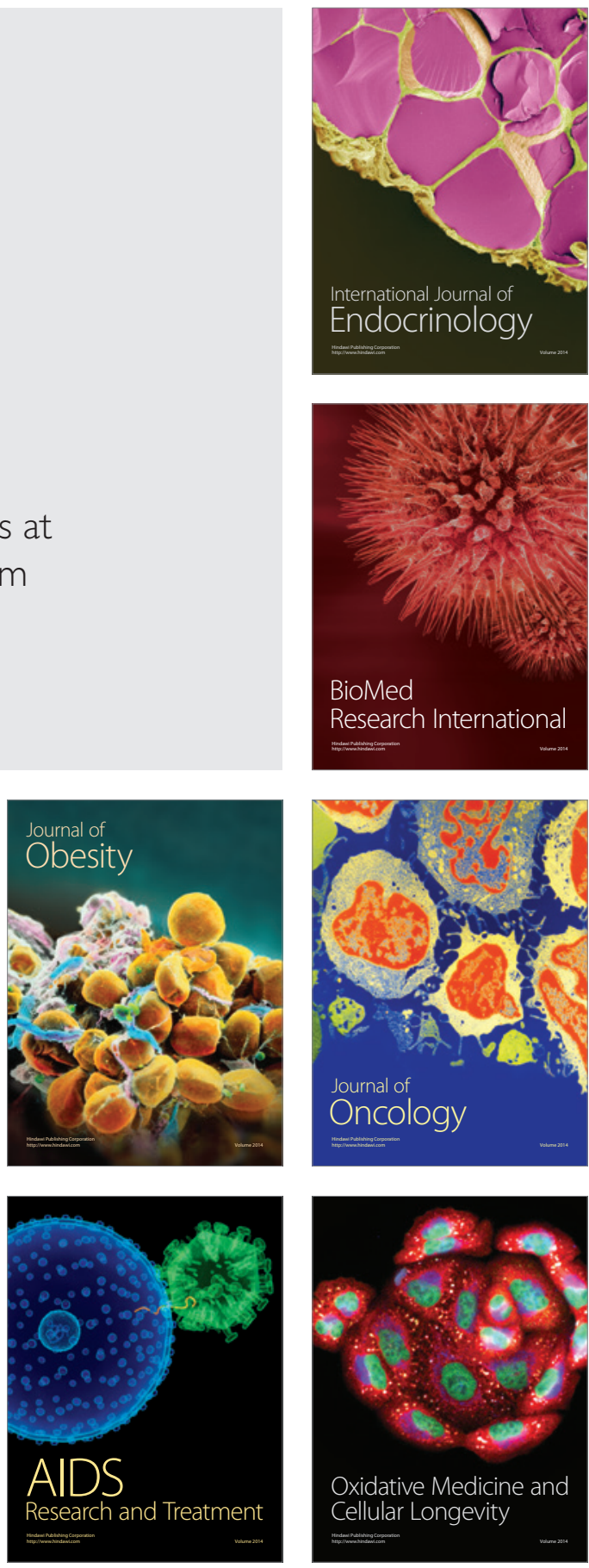